\title{
Plasma Prostaglandin and Cytokine Concentrations in Periparturient Holstein Cows Fed Diets Enriched in Saturated or Trans Fatty Acids
}

\author{
C. Rodriguez-Sallaberry, C. Caldari-Torres, W. Collante, C. R. Staples, and L. Badinga ${ }^{1}$ \\ Department of Animal Sciences, University of Florida, Gainesville 32611
}

\begin{abstract}
After parturition, immune functions such as lymphocyte response to mitogens and production of antibodies are depressed in dairy cows. Dietary regimens that improve the immune function of dairy cows after calving may improve uterine health and lead to earlier breeding after parturition. The objective of this study was to examine the effect of feeding a calcium salt of trans isomers of fatty acids $(t \mathrm{FA})$ to periparturient Holstein cows on plasma biomarkers of inflammation. Dietary treatments were initiated approximately $28 \mathrm{~d}$ before expected calving date and continued through d 21 postpartum. Prepartum and postpartum diets were formulated to be isolipidic, containing $1.5 \%$ saturated fats $(\mathrm{n}=15)$ or $1.8 \% t \mathrm{FA}(\mathrm{n}=15)$. Multiparous cows were heavier at calving $(+32 \%)$ and produced more milk $(+17 \%)$ than primiparous cows. Periparturient $t$ FA supplementation increased plasma $\mathrm{PGF}_{2 \alpha}$ metabolite concentration in multiparous cows, but not in primiparous cows. Concentrations of prostaglandin $\mathrm{E}_{2}$, tumor necrosis factor-alpha, and interleukin- 4 in plasma did not differ between diets and parities. Results raise the possibility that peripartum $t \mathrm{FA}$ supplementation may affect uterine health and reproductive efficiency of early lactation dairy cows through alteration of peripheral $\mathrm{PGF}_{2 \alpha}$ concentration.
\end{abstract}

Key words: fat, prostaglandin, cytokine, dairy cow

\section{INTRODUCTION}

Dietary fatty acids (FA) can alter immunity through influencing the production of cytokines and other molecules involved in the regulation of immune responses (Han et al., 2002; Lessard et al., 2003). Immunomodulatory effects of supplemental fats are mediated, in part, by alteration of prostaglandin (PG) synthesis (Han et al., 2002). Eicosanoids derived from arachidonic acid (ARA) and eicosapentaenoic acid have similar molecu-

Received March 15, 2007.

Accepted September 4, 2007.

${ }^{1}$ Corresponding author: lbadinga@ufl.edu lar structures, but they differ markedly in their biological properties (Wander et al., 1997). The eicosapentaenoic acid-derived eicosanoids (i.e., $\mathbf{P G E} \mathbf{E}_{3}$ and leukotriene $B_{5}$ ) are generally much less potent inducers of inflammation than the ARA-derived eicosanoids (Yaqoob and Calder, 1995; Wander et al., 1997). This has led to the proposition that a reduction in the amount of the more inflammatory prostaglandins derived from ARA (i.e., $\mathbf{P G E}_{\mathbf{2}}$ and leukotriene $\mathrm{B}_{4}$ ) may account for the antiinflammatory effects of fish oil (Meydani and Dinarello, 1993).

Trans fatty acids ( $t$ FA) refer to isomeric unsaturated fatty acids containing one or more double bond in the trans configuration (Mozaffarian et al., 2004b). These FA are formed in the rumen or during the industrial hydrogenation of vegetable oils for food manufacturing (Kepler et al., 1966; Mozaffarian et al., 2004a). Ruminant and industrial fats contain the same $t \mathrm{FA}$ isomers, but their isomeric profiles differ considerably (Weggemans et al., 2004). Vaccenic acid $\left(\mathrm{C}_{18: 1} \Delta^{11} t\right)$ is the major component of the $t \mathrm{FA}$ in ruminant fat, whereas elaidic acid $\left(\mathrm{C}_{18: 1} \Delta^{9} t\right)$ is generally considered the isomer typical of industrial hydrogenation (Wolff et al., 1998). Unlike human studies, many of the reported detrimental effects of trans isomers in animals are thought to result from essential FA deficiency rather than from a specific effect of trans isomers because they can be prevented by increasing essential FA availability (Gurr, 1983; BeareRodgers, 1988; Mahfouz and Kummerow, 1999). Consequently, it is difficult to ascertain whether some of the effects associated with supplemental $t \mathrm{FA}$ are due to $t$ FA or to essential FA deficiencies.

Human studies have shown that $t \mathrm{FA}$ intake increases systemic inflammation through the production of inflammatory cytokines (Han et al., 2002). Based on this human model, we hypothesized that dietary $t \mathrm{FA}$ may increase plasma concentration of proinflammatory cytokines such as tumor necrosis factor-alpha (TNF- $\alpha$ and decrease circulating concentration of antiinflammatory cytokines such as interleukin-4 (IL-4) in early postpartum dairy cows. The specific objective of this study therefore was to examine the effect of feeding a calcium salt of $t \mathrm{FA}$ to periparturient Holstein cows on plasma biomarkers of inflammation. 


\section{MATERIALS AND METHODS}

\section{Animals, Treatments, and Sampling}

All experimental animals were managed according to the guidelines approved by the University of Florida Animal Care and Use committee. Eighteen multiparous (parity $\geq 2$ ) and 12 primiparous Holstein cows were used in a completely randomized design to examine the effect of feeding a calcium salt of $t \mathrm{FA}$ (EnerGI Transition Formula; Virtus Nutrition, Fairlawn, $\mathrm{OH}$ ) on milk production, milk composition, and plasma concentrations of $\mathrm{PGF}_{2 \alpha}$ metabolite (PGFM), PGE 2 , TNF- $\alpha$, IL-4, glucose, NEFA, and BHBA. The average length of the nonlactating period of the multiparous cows was $80.1 \pm$ $32.2 \mathrm{~d}$ (range from 51 to $183 \mathrm{~d}$ ). During the nonlactating period, the multiparous cows were housed on bermudagrass-based pasture and fed a TMR composed of $55 \%$ sorghum silage, $13.6 \%$ soybean meal, $11.7 \%$ ground corn, $11.6 \%$ citrus pulp, $6.7 \%$ molasses, and $1.9 \%$ mineral-vitamin mix (DM basis) in limited amounts to maintain body condition at dry-off. Prior to moving the pregnant primiparous cows into the experiment, a TMR of $40 \%$ sorghum silage, $25 \%$ oat silage, $10.3 \%$ citrus pulp, $7 \%$ soybean meal, $7 \%$ cottonseed meal, $6 \%$ corn, $3 \%$ molasses, and 1.7\% mineral-vitamin mix (DM basis) was fed to heifers housed on bermudagrass pastures. Diet was to support $0.9 \mathrm{~kg}$ of BW gain daily. All animals calved in the sod-based pen area associated with the Calan gate feeding system; thus, the dietary treatment assigned to each animal was available continuously throughout the calving process. Within $12 \mathrm{~h}$ of calving, animals were moved to a free-stall barn and offered their assigned dietary TMR via Calan gate. Dietary treatments [saturated fats (SF) and calcium salt of $t$ FA] were initiated approximately $28 \mathrm{~d}$ before calculated calving dates and continued through d 21 postpartum. Prepartum and postpartum diets were formulated to contain $1.5 \% \mathrm{SF}$ or $1.8 \%$ calcium salt of $t \mathrm{FA}$ (DM basis). Fat supplements were mixed with the concentrates and offered as part of the TMR to experimental animals. Saturated FA made up $91.4 \%$ of the SF supplement, whereas trans isomers of $\mathrm{C}_{18: 1}$ made up $57.5 \%$ of the $t$ FA supplement (Table 1).

Prepartum cows were housed in pens equipped with shaded Calan gates (American Calan Inc., Northwood, $\mathrm{NH}$ ). Postpartum cows were managed in a free-stall barn equipped with fans, sprinklers, and Calan gates. The study was conducted from March to July 2005. Intake of DM was measured daily during the entire experimental period. All animals were offered ad libitum amounts of TMR to allow for 5 to $10 \%$ refusals. Corn silage was the major forage component, and ground corn was the primary concentrate. Dry matter of corn silage was determined weekly $\left(55^{\circ} \mathrm{C}\right.$ for $\left.48 \mathrm{~h}\right)$,
Table 1. Fatty acid profile of dietary fat supplements

\begin{tabular}{|c|c|c|}
\hline \multirow[b]{2}{*}{ Fatty acid } & \multicolumn{2}{|c|}{ Fat supplement ${ }^{1}$} \\
\hline & SF & $t \mathrm{FA}$ \\
\hline & - g & $\mathrm{ds} \longrightarrow$ \\
\hline $\mathrm{C}_{12: 0}$ & - & 0.04 \\
\hline $\mathrm{C}_{14: 0}$ & 5.6 & 0.31 \\
\hline $\mathrm{C}_{16.0}$ & 37.8 & 12.21 \\
\hline $\mathrm{C}_{16: 1}$ & - & 0.15 \\
\hline $\mathrm{C}_{18: 0}$ & 48.0 & 6.70 \\
\hline $\mathrm{C}_{18: 1}$, trans $-6-8$ & - & 20.62 \\
\hline $\mathrm{C}_{18: 1}$, trans -9 & - & 10.47 \\
\hline $\mathrm{C}_{18: 1}$, trans -10 & - & 10.62 \\
\hline $\mathrm{C}_{18: 1}$, trans -11 & - & 7.05 \\
\hline $\mathrm{C}_{18: 1}$, trans -12 & - & 8.73 \\
\hline $\mathrm{C}_{18: 1}$, cis -9 & 4.8 & 10.04 \\
\hline $\mathrm{C}_{18: 2}$, cis -9, cis -12 & - & 1.97 \\
\hline Unknown $^{2}$ & 3.8 & 11.07 \\
\hline
\end{tabular}

${ }^{1}$ Fat supplements: $\mathrm{SF}$ = saturated fats. Rumen Bypass Fat manufactured by Cargill (Minneapolis, MN); $t \mathrm{FA}=$ trans fatty acids. EnerG1 Transition Formula manufactured by Virtus Nutrition (Fairlawn, $\mathrm{OH})$.

${ }^{2}$ Unknown $=$ fractions of total peak area that have not been identified.

and the rations were adjusted accordingly to maintain a constant forage:concentrate ratio on a DM basis.

Postpartum cows were milked 3 times per day, and milk weights were recorded at each milking. For each experimental animal, samples of milk from 2 consecutive morning $(1000 \mathrm{~h})$ and evening $(1800 \mathrm{~h})$ milkings were collected at the end of the experimental period (d 21 postpartum) and analyzed for fat, protein, and SCC. Milk fat and protein concentrations were determined using a midinfrared spectrophotometer equipped with an A and B filter (model B2000, Bentley Instruments, Chaska, MN). Two milk samples collected at 8-h intervals provide good estimates of milk fat content of a full day's production for herds milked 3 times per day (Wiggans, 1986). Body weights were measured and BCS assigned weekly by the same individual.

Blood $(\sim 20 \mathrm{~mL})$ was collected by puncture of a tail artery or vein once daily at $1730 \mathrm{~h}$ from d 14 before calculated calving date until parturition (d 0) and from d 15 until d 21 postpartum. Between the calving day and d 14 postpartum, blood samples were collected twice per day at 0800 and $1730 \mathrm{~h}$. Samples were centrifuged at 2,500 $\times \mathrm{g}$ for $30 \mathrm{~min}$ at $4^{\circ} \mathrm{C}$. Plasma was separated and stored at $-20^{\circ} \mathrm{C}$ for subsequent chemical analyses.

\section{Chemical Analysis}

Samples of forages and concentrate mixes were collected weekly and composited monthly for fat (AOAC, 1990; Dairy One, Ithaca, NY), mineral (Dairy One, Ithaca, NY), CP (Elementar, Hanau, Germany), ADF 
Table 2. Ingredient composition of prepartum and postpartum diets

\begin{tabular}{|c|c|c|}
\hline Ingredient & Prepartum & Postpartum \\
\hline & \multicolumn{2}{|c|}{ \% of DM } \\
\hline Corn silage & 45.0 & 37.5 \\
\hline Bermudagrass hay & 15.0 & - \\
\hline Alfalfa hay & - & 11.9 \\
\hline Ground corn & 14.5 & 20.3 \\
\hline Soybean meal & 12.4 & 7.6 \\
\hline Extruded soybean meal ${ }^{1}$ & - & 13.4 \\
\hline Citrus pulp & 4.9 & - \\
\hline Cottonseed hulls & - & 2.5 \\
\hline Fat supplement ${ }^{2}$ & 1.5 or 1.8 & 1.5 or 1.8 \\
\hline Mineral and vitamin $\operatorname{mix}^{3}$ & 6.5 & - \\
\hline Mineral and vitamin $\operatorname{mix}^{4}$ & - & 4.8 \\
\hline Trace mineralized salt ${ }^{5}$ & 0.1 & - \\
\hline Biophos $^{6}$ & - & 0.3 \\
\hline
\end{tabular}

${ }^{1}$ West Central Soy (Ralston, IA).

${ }^{2} 1.5 \%$ saturated fat supplement (Rumen Bypass Fat, Cargill, Minneapolis, MN) or $1.8 \%$ calcium salt lipid enriched in trans 18:1 fatty acids (EnerG1 Transition Formula, Virtus Nutrition, Fairlawn, $\mathrm{OH}$ )

${ }^{3}$ Mineral and vitamin mix contained $22.8 \% \mathrm{CP}, 2.1 \%$ fat, $22.89 \%$ $\mathrm{Ca}, 0.16 \% \mathrm{P}, 2.77 \% \mathrm{Mg}, 0.75 \% \mathrm{Na}, 0.20 \% \mathrm{~K}, 2.42 \% \mathrm{~S}, 8.03 \% \mathrm{Cl}, 150$ $\mathrm{mg}$ of $\mathrm{Mn} / \mathrm{kg}, 97 \mathrm{mg}$ of $\mathrm{Zn} / \mathrm{kg}, 168 \mathrm{mg}$ of $\mathrm{Fe} / \mathrm{kg}, 186 \mathrm{mg}$ of $\mathrm{Cu} / \mathrm{kg}, 11$ $\mathrm{mg}$ of Co/kg, $8.4 \mathrm{mg}$ of I/kg, $6.9 \mathrm{mg}$ of Se/kg, 268,130 IU of vitamin $\mathrm{A} / \mathrm{kg}, 40,000 \mathrm{IU}$ of vitamin $\mathrm{D} / \mathrm{kg}$, and 1,129 IU of vitamin $\mathrm{E} / \mathrm{kg}$ (DM basis).

${ }^{4}$ Mineral and vitamin mix contained $26.4 \% \mathrm{CP}, 1.74 \%$ fat, $10.15 \%$ $\mathrm{Ca}, 0.90 \% \mathrm{P}, 3.1 \% \mathrm{Mg}, 8.6 \% \mathrm{Na}, 5.1 \% \mathrm{~K}, 1.5 \% \mathrm{~S}, 4.1 \% \mathrm{Cl}, 2,231 \mathrm{mg}$ of $\mathrm{Mn} / \mathrm{kg}, 1,698 \mathrm{mg}$ of $\mathrm{Zn} / \mathrm{kg}, 339 \mathrm{mg}$ of $\mathrm{Fe} / \mathrm{kg}, 512 \mathrm{mg}$ of $\mathrm{Cu} / \mathrm{kg}, 31$ $\mathrm{mg}$ of Co/kg, $26 \mathrm{mg}$ of $\mathrm{I} / \mathrm{kg}, 7.9 \mathrm{mg}$ of Se/kg, 147,756 IU of vitamin $\mathrm{A} / \mathrm{kg}, 43,750 \mathrm{IU}$ of vitamin $\mathrm{D} / \mathrm{kg}$, and $787 \mathrm{IU}$ of vitamin $\mathrm{E} / \mathrm{kg}$ (DM basis).

${ }^{5}$ Mineral concentrations of $40 \% \mathrm{Na}, 55 \% \mathrm{Cl}, 0.25 \% \mathrm{Mn}, 0.2 \% \mathrm{Fe}$, $0.033 \% \mathrm{Cu}, 0.007 \% \mathrm{I}, 0.005 \% \mathrm{Zn}$, and $0.0025 \% \mathrm{Co}$ (DM basis).

${ }^{6} \mathrm{IMC}$ - Agrico (Bannockburn, IL).

(AOAC, 1990), and NDF (Van Soest et al., 1991) analyses. Ingredient and chemical compositions of experimental diets are listed in Tables 2 and 3, respectively.

Concentrations of NEFA, BHBA, and glucose in plasma samples collected on $\mathrm{d}-14,-7,7,14$, and 21 (d $0=\mathrm{d}$ of calving) were measured enzymatically with commercial kits (Wako Chemicals USA Inc., Richmond, VA). Intra- and interassay CV were 2.0 and $5.2 \%, 0.8$ and $2.0 \%$, and 1.2 and $1.9 \%$, for NEFA, BHBA, and glucose, respectively. Least detectable concentrations were $50 \mu \mathrm{Eq} / \mathrm{L}, 0.5 \mu \mathrm{mol} / \mathrm{L}$, and $25 \mathrm{mg} / \mathrm{dL}$ for NEFA, BHBA, and glucose, respectively.

Plasma PGFM concentration was measured as described by Mattos et al. (2004). Briefly, standards (100 $\mu \mathrm{L}$; range 15.0 to $8,000 \mathrm{pg} / \mathrm{mL}$ ) or plasma samples (100 $\mu \mathrm{L}$ ) were incubated with rabbit antibovine PGFM antibody $(100 \mu \mathrm{L}$ diluted to $1: 5,000)$ and ${ }^{3} \mathrm{H}-\mathrm{PGFM}$ (adjusted to $18,000 \mathrm{dpm} / 100 \mu \mathrm{L}$; specific activity $=174 \mathrm{Ci} /$ mmol; Amersham Biosciences Corp., Piscataway, NJ) for $24 \mathrm{~h}$ at $4^{\circ} \mathrm{C}$. The standard tubes contained $100 \mu \mathrm{L}$ of low-PGFM plasma collected from d 30 postpartum cows. Antigen-antibody complexes were separated from unbound PGFM by the addition of a dextran-coated
Table 3. Chemical composition of prepartum and postpartum diets

\begin{tabular}{|c|c|c|c|c|}
\hline \multirow[b]{2}{*}{ Ingredient } & \multicolumn{2}{|c|}{ Prepartum } & \multicolumn{2}{|c|}{ Postpartum } \\
\hline & $\mathrm{SF}^{1}$ & $t \mathrm{FA}^{2}$ & $\mathrm{SF}$ & $t \mathrm{FA}$ \\
\hline $\mathrm{DM}, \%$ & 47.2 & 47.2 & 50.9 & 50.9 \\
\hline $\mathrm{CP}, \%$ of $\mathrm{DM}$ & 13.8 & 14.0 & 17.2 & 16.9 \\
\hline $\mathrm{ADF}, \%$ of $\mathrm{DM}$ & 22.1 & 22.3 & 17.8 & 17.8 \\
\hline $\mathrm{NDF}, \%$ of $\mathrm{DM}$ & 37.4 & 37.7 & 31.1 & 31.2 \\
\hline Lipid, \% of DM & 3.89 & 4.05 & 6.04 & 5.54 \\
\hline $\mathrm{NE}_{\mathrm{L}}, \mathrm{Mcal} / \mathrm{kg}$ & 1.53 & 1.53 & 1.67 & 1.67 \\
\hline $\mathrm{Ca}, \%$ of $\mathrm{DM}$ & 1.78 & 1.83 & 1.02 & 1.11 \\
\hline $\mathrm{P}, \%$ of $\mathrm{DM}$ & 0.33 & 0.34 & 0.48 & 0.47 \\
\hline $\mathrm{Mg}, \%$ of $\mathrm{DM}$ & 0.33 & 0.34 & 0.34 & 0.34 \\
\hline $\mathrm{K}, \%$ of DM & 1.30 & 1.32 & 1.56 & 1.57 \\
\hline $\mathrm{Na}, \%$ of $\mathrm{DM}$ & 0.20 & 0.19 & 0.45 & 0.43 \\
\hline $\mathrm{Fe}, \mathrm{mg} / \mathrm{kg}$ & 563 & 541 & 417 & 425 \\
\hline $\mathrm{Zn}, \mathrm{mg} / \mathrm{kg}$ & 65 & 58 & 92 & 90 \\
\hline $\mathrm{Cu}, \mathrm{mg} / \mathrm{kg}$ & 27 & 23 & 32 & 37 \\
\hline $\mathrm{Mn}, \mathrm{mg} / \mathrm{kg}$ & 67 & 61 & 92 & 88 \\
\hline Mo, mg/kg & 0.77 & 0.97 & 1.40 & 1.10 \\
\hline
\end{tabular}

${ }^{1} \mathrm{SF}=$ saturated fats. Rumen Bypass Fat manufactured by Cargill (Minneapolis, MN).

${ }^{2} t \mathrm{FA}=$ trans fatty acids. EnerG1 Transition Formula manufactured by Virtus Nutrition (Fairlawn, $\mathrm{OH}$ ).

charcoal solution. The least detectable concentration was $15 \mathrm{pg} / \mathrm{mL}$, and intra- and interassay CV were 6.5 and $5.9 \%$, respectively. Concentration of $\mathrm{PGE}_{2}$ in plasma was measured using a commercial radioimmunoassay kit (Sigma Chemical Co., St. Louis, MO). Tritiated $\mathrm{PGE}_{2}$ (specific activity $=190 \mathrm{Ci} / \mathrm{mmol}$ ) was obtained from Amersham Biosciences Corp. (Piscataway, NJ). The anti-PGE $\mathrm{E}_{2}$ was from Sigma Chemical Co. (St. Louis, MO). The least detectable concentration was 150 $\mathrm{pg} / \mathrm{mL}$, and intra- and interassay CV were 4.0 and $6.2 \%$, respectively.

Plasma TNF- $\alpha$ and IL-4 concentrations were determined using commercial ELISA kits (Endogen, Pierce, Rockford, IL). Samples were run in triplicates, and intra- and interassay CV were 0.8 and $2.6 \%$ for TNF- $\alpha$. Corresponding values were 2.1 and $10.2 \%$ for IL-4. Least detectable concentrations were 25 and $1 \mathrm{pg} / \mathrm{mL}$ for TNF- $\alpha$ and IL-4, respectively.

\section{Statistical Analysis}

Performance, metabolic and hormonal responses were analyzed using the MIXED procedure of SAS (SAS Institute Inc., Cary, NC). Fixed effects included dietary treatment, parity, day relative to calving, and appropriate 2- and 3-way interactions. The variance of cow, nested within treatment and parity, was used as random error term to test the effects of treatment, parity, and treatment $\times$ parity. Separate analyses were conducted for pre- and postpartum periods. Differential temporal responses to dietary treatment and parity were further examined using the SLICE option of the MIXED procedure. Means for dietary treatment, parity, 
Table 4. Prepartum and postpartum performance of primiparous and multiparous Holstein cows fed diets enriched in highly saturated fats (SF) or trans-18:1 ( $t \mathrm{FA})$

\begin{tabular}{|c|c|c|c|c|c|c|c|c|}
\hline \multirow[b]{2}{*}{ Item } & \multicolumn{2}{|c|}{ Primiparous cows } & \multicolumn{2}{|c|}{ Multiparous cows } & \multirow[b]{2}{*}{ SEM } & \multicolumn{3}{|c|}{$P$-value ${ }^{1}$} \\
\hline & $\mathrm{SF}^{2}$ & $t \mathrm{FA}^{3}$ & $\mathrm{SF}$ & $t \mathrm{FA}$ & & $\mathrm{P}$ & $\mathrm{D}$ & $\mathrm{P} \times \mathrm{D}$ \\
\hline \multicolumn{9}{|l|}{ Prepartum } \\
\hline $\mathrm{BW}, \mathrm{kg}$ & 568 & 570 & 748 & 753 & 6 & 0.0001 & 0.87 & 0.96 \\
\hline DMI, kg/d & 9.9 & 9.4 & 13.8 & 11.9 & 0.2 & 0.001 & 0.15 & 0.41 \\
\hline \multicolumn{9}{|l|}{ Postpartum } \\
\hline BW, kg & 514 & 507 & 672 & 665 & 5.0 & 0.0001 & 0.75 & 0.99 \\
\hline DMI, kg/d & 13.3 & 11.8 & 16.5 & 14.3 & 0.5 & 0.03 & 0.14 & 0.76 \\
\hline
\end{tabular}

and day relative to calving were considered different at $P<0.05$. The incidence of health disorders was evaluated by $\chi^{2}$ analysis using the FREQUENCY procedure of SAS (SAS Institute Inc., Cary, NC).

\section{RESULTS}

\section{Production and Metabolic Responses to Dietary Fats}

Peripartum $t$ FA supplementation had minimal effects on production and metabolic responses of Holstein cows (Tables 4, 5, and 6). Multiparous cows were heavier at calving $(+32 \% ; P=0.0001)$ and produced more milk ( $+17 \% ; P=0.02)$ than primiparous cows during the first 3 wk of lactation. Parity $\times$ diet interactions were detected for prepartum plasma glucose $(P=0.02)$ and postpartum NEFA $(P=0.04)$ concentrations (Table $5)$. During the prepartum period, $t \mathrm{FA}$ supplementation decreased plasma glucose concentration in primiparous but not multiparous cows. After calving, plasma NEFA concentration increased in multiparous cows fed the $t$ FA-supplemented diet. Milk protein concentration was greater $(+7 \% ; P=0.03)$ in multiparous than primipa- rous cows (Table 6). There were no differences in milk fat concentration or SCC due to parity or diet (Table 6). Diets did not affect the incidence of postpartum metritis (control $=27 \%, t \mathrm{FA}=7 \% ; P=0.36)$, retained placenta (control $=13 \%, t \mathrm{FA}=20 \% ; P=0.44)$ or displaced abomasums (control $=7 \%, t \mathrm{FA}=13 \% ; P=0.36$ ).

\section{Plasma Prostaglandin and Cytokine Responses to Dietary Fats}

A parity $\times$ treatment $\times$ day interaction was detected $(P=0.002)$ for plasma PGFM concentration (Figure 1$)$. Peripheral PGFM concentration rose at faster rate and was greater in multiparous Holstein cows fed a $t \mathrm{FA}-$ supplemented diet than those receiving a diet enriched in saturated FA. Least squares means at $d 2.5$ postpartum were different $(P=0.01)$. Conversely, in primiparous cows, dietary treatment had no detectable effects $(P=0.33)$ on pattern of plasma PGFM concentration during the first week of lactation (Figure 1A). Plasma $\mathrm{PGE}_{2}$ concentration increased $(P=0.0001)$ from $5.5 \pm$ $0.2 \mathrm{ng} / \mathrm{mL}$ to $6.6 \pm 0.2 \mathrm{ng} / \mathrm{mL}$ between $\mathrm{d} 2$ and 1 before parturition and then decreased to less than $1 \mathrm{ng} / \mathrm{mL}$ by

Table 5. Prepartum and postpartum plasma metabolites in primiparous and multiparous Holstein cows fed diets enriched in highly saturated fats $(\mathrm{SF})$ or trans-18:1 $(t \mathrm{FA})$

\begin{tabular}{|c|c|c|c|c|c|c|c|c|}
\hline \multirow[b]{2}{*}{ Item } & \multicolumn{2}{|c|}{ Primiparous cows } & \multicolumn{2}{|c|}{ Multiparous cows } & \multirow[b]{2}{*}{ SEM } & \multicolumn{3}{|c|}{$P$-value ${ }^{1}$} \\
\hline & $\mathrm{SF}^{2}$ & $t \mathrm{FA}^{3}$ & $\mathrm{SF}$ & $t \mathrm{FA}$ & & $\mathrm{P}$ & $\mathrm{D}$ & $\mathrm{P} \times \mathrm{D}$ \\
\hline \multicolumn{9}{|l|}{ Prepartum } \\
\hline NEFA, $\mu \mathrm{Eq} / \mathrm{L}$ & 108 & 177 & 84 & 169 & 19 & 0.71 & 0.07 & 0.84 \\
\hline $\mathrm{BHBA}, \mu \mathrm{mol} / \mathrm{L}$ & 1.9 & 2.1 & 2.5 & 2.5 & 0.2 & 0.04 & 0.70 & 0.60 \\
\hline Glucose, mg/dL & 62.8 & 57.5 & 60.0 & 62.2 & 1.0 & 0.54 & 0.34 & 0.02 \\
\hline \multicolumn{9}{|l|}{ Postpartum } \\
\hline NEFA, $\mu \mathrm{Eq} / \mathrm{L}$ & 445 & 330 & 348 & 558 & 75 & 0.39 & 0.53 & 0.04 \\
\hline $\mathrm{BHBA}, \mu \mathrm{mol} / \mathrm{L}$ & 5.6 & 3.9 & 4.6 & 5.9 & 0.8 & 0.54 & 0.82 & 0.07 \\
\hline Glucose, mg/dL & 54.5 & 55.6 & 52.2 & 48.3 & 2.2 & 0.04 & 0.54 & 0.27 \\
\hline
\end{tabular}

${ }^{1} \mathrm{P}=$ parity; $\mathrm{D}=$ diet; and $\mathrm{P} \times \mathrm{D}=$ parity $\times$ diet interaction

${ }^{2} \mathrm{SF}=$ saturated fats. Rumen Bypass Fat manufactured by Cargill (Minneapolis, MN).

${ }^{3} t \mathrm{FA}=$ trans fatty acids. EnerG1 Transition Formula manufactured by Virtus Nutrition (Fairlawn, OH). 
Table 6. Milk production and composition of primiparous and multiparous Holstein cows fed diets enriched in highly saturated fats (SF) or trans-18:1 $(t \mathrm{FA})$ at wk 3 of lactation

\begin{tabular}{|c|c|c|c|c|c|c|c|c|}
\hline \multirow[b]{2}{*}{ Item } & \multicolumn{2}{|c|}{ Primiparous cows } & \multicolumn{2}{|c|}{ Multiparous cows } & \multirow[b]{2}{*}{ SEM } & \multicolumn{3}{|c|}{$P$-value ${ }^{1}$} \\
\hline & $\mathrm{SF}^{2}$ & $t \mathrm{FA}^{3}$ & $\mathrm{SF}$ & $t \mathrm{FA}$ & & $\mathrm{P}$ & $\mathrm{D}$ & $\mathrm{P} \times \mathrm{D}$ \\
\hline $\begin{array}{l}\text { Milk yield, kg/d } \\
\text { Milk fat }\end{array}$ & 30.7 & 28.9 & 36.5 & 33.5 & 0.9 & 0.02 & 0.24 & 0.77 \\
\hline$\%$ & 3.34 & 3.49 & 3.49 & 3.64 & 0.21 & 0.47 & 0.48 & 0.99 \\
\hline $\mathrm{kg} / \mathrm{d}$ & 0.79 & 0.78 & 0.95 & 0.93 & 0.10 & 0.13 & 0.89 & 0.94 \\
\hline Milk protein & & & & & & & & \\
\hline$\%$ & 2.72 & 2.63 & 2.79 & 2.92 & 0.07 & 0.03 & 0.79 & 0.18 \\
\hline $\mathrm{kg} / \mathrm{d}$ & 0.63 & 0.59 & 0.76 & 0.76 & 0.07 & 0.06 & 0.83 & 0.81 \\
\hline $\operatorname{SCC}(\times 1,000)$ & 423 & 825 & 104 & 770 & 462 & 0.69 & 0.26 & 0.78 \\
\hline
\end{tabular}

${ }^{1} \mathrm{P}=$ parity; $\mathrm{D}=$ diet; and $\mathrm{P} \times \mathrm{D}=$ parity $\times$ diet interaction.

${ }^{2} \mathrm{SF}=$ saturated fats. Rumen Bypass Fat manufactured by Cargill (Minneapolis, MN).

${ }^{3} t \mathrm{FA}=$ trans fatty acids. EnerG1 Transition Formula manufactured by Virtus Nutrition (Fairlawn, $\mathrm{OH}$ ).

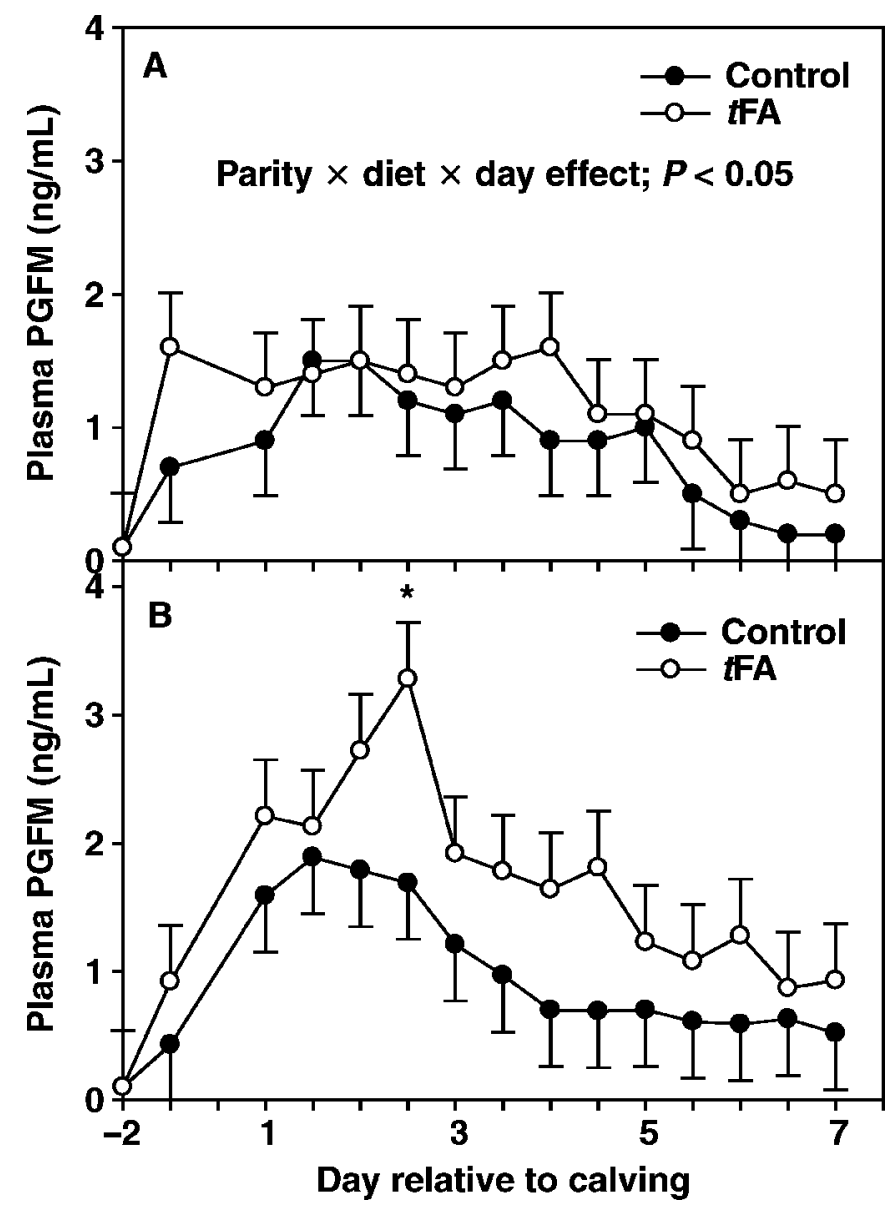

Figure 1. Plasma prostaglandin $\mathrm{F}_{2 \alpha}$ metabolite (PGFM) concentrations in primiparous (A) and multiparous (B) Holstein cows fed diets enriched in highly saturated fats $(\mathrm{SF})$ or trans-18:1 $(t \mathrm{FA})$. Data represent least squares means and SEM for 6 primiparous and 9 multiparous cows per dietary treatment. A parity $\times$ diet $\times$ day interaction was detected $(P=0.002)$. Asterisk indicates that mean PGFM concentration at the indicated time differed between diets. d 1 postpartum. There were no differences in peripheral $\mathrm{PGE}_{2}$ due to parity $(P=0.90)$ or dietary treatment $(P=$ 0.57). Plasma TNF- $\alpha$ and IL-4 concentrations did not differ between parities or treatments (Table 7).

\section{DISCUSSION}

The present study provides no evidence for $t$ FA modulation of milk production or composition in early postpartum Holstein cows. These findings are consistent with a previous study (Piperova et al., 2004) in which $t$ FA failed to alter milk production in midlactation dairy cows. The lack of $t$ FA effect on milk composition is also consistent with previous studies in which conjugated linoleic acid supplementation during the early lactation period had minimal effect on milk fat and protein contents (Bernal-Santos et al., 2003; Castaneda-Gutierrez et al., 2005). These results collectively indicate that the net effect of supplemental fat on milk composition may vary, depending on isomeric composition of fat supplements and the stage of lactation when fat supplementation is implemented. The greater prepartum blood glucose concentration in multiparous cows fed the $t$ FA supplement compared with primiparous cows fed the same diet would indicate that older cows may have greater gluconeogenic capacity, and therefore were better able to offset the decreased glucose precursor availability due to decreased DMI. Alternatively, increased gluconeogenesis in older cows may reflect a sustained supply of NEFAs, which are known to increase glucose output in humans (Shah et al., 2002) and cattle (Strang et al., 1998).

Plasma PGFM concentration was greater in multiparous cows fed a $t \mathrm{FA}$-supplemented diet than those receiving an isocaloric control diet enriched in saturated fats. Conversely, in primiparous cows, dietary treatment had no detectable effects on peripheral PGFM concentration after calving. To the best of our knowl- 
Table 7. Prepartum and postpartum plasma tumor necrosis factor- $\alpha$ (TNF- $\alpha$ ) and interleukin-4 (IL-4) concentrations in primiparous and multiparous Holstein cows fed diets enriched in highly saturated fats (SF) or trans-18:1 $(t \mathrm{FA})$

\begin{tabular}{|c|c|c|c|c|c|c|c|c|}
\hline \multirow[b]{2}{*}{ Item } & \multicolumn{2}{|c|}{ Primiparous cows } & \multicolumn{2}{|c|}{ Multiparous cows } & \multirow[b]{2}{*}{ SEM } & \multicolumn{3}{|c|}{$P$-value ${ }^{1}$} \\
\hline & $\mathrm{SF}^{2}$ & $t \mathrm{FA}^{3}$ & $\mathrm{SF}$ & $t \mathrm{FA}$ & & $\mathrm{P}$ & $\mathrm{D}$ & $\mathrm{P} \times \mathrm{D}$ \\
\hline \multicolumn{9}{|l|}{ Prepartum } \\
\hline TNF- $\alpha, \mathrm{pg} / \mathrm{mL}$ & 47.3 & 36.3 & 60.0 & 55.8 & 14.7 & 0.29 & 0.61 & 0.82 \\
\hline $\mathrm{IL}-4, \mathrm{pg} / \mathrm{mL}$ & 1.0 & 4.8 & 9.4 & 7.0 & 6.2 & 0.41 & 0.91 & 0.62 \\
\hline \multicolumn{9}{|l|}{ Postpartum } \\
\hline TNF- $\alpha, \mathrm{pg} / \mathrm{mL}$ & 79.0 & 32.8 & 69.7 & 46.2 & 20.0 & 0.92 & 0.10 & 0.58 \\
\hline $\mathrm{IL}-4, \mathrm{pg} / \mathrm{mL}$ & 3.4 & 8.8 & 12.1 & 8.6 & 7.8 & 0.59 & 0.90 & 0.57 \\
\hline
\end{tabular}

edge, this is the first report of a positive relationship between trans fat feeding and peripheral concentration of PGFM in multiparous cows, and the physiological relevance of this association is yet to be elucidated. Available evidence indicates that multiparous cows are more likely to develop postpartum hypocalcemia as a result of increased milk output (Goff and Horst, 1997). Such a decrease in plasma calcium concentration may affect the signaling mechanism within the cell and alter the animal's ability to respond to hormonal or dietary treatment. Whether this was the case in the present study is unknown because the current experiment did not examine the calcium status of experimental animals. Other studies have shown that the parity number influences neutrophil functions in dairy cows (Gilbert et al., 1993) and that these immune differences between primiparous and multiparous cows may be related to increased risk of developing several postpartum complications in cows with greater parity number (Curtis et al., 1985; Grohn et al., 1990).

The mechanism(s) by which circulating $\mathrm{PGF}_{2 \alpha}$ improves uterine health in cattle is multifaceted and may vary with the number of lactations. Because exogenous $\mathrm{PGF}_{2 \alpha}$ is luteolytic in ruminants (McCracken et al., 1972; Thatcher et al., 1984), its mechanism of action has been presumed to be related to reductions in circulating progesterone concentrations and the resulting up-regulation of immune functions (Bonnett et al., 1990; Lewis and Wulster-Radcliffe, 2006). This does not rule out, however, the possibility that supplemental $\mathrm{PGF}_{2 \alpha}$ may affect immune functions through mechanisms that are independent of its effects on luteal function. In this regard, treatment of cows with fenprostalene between d 7 and 10 postpartum, when progesterone concentrations are typically basal, reduced the incidence of endometritis in dairy cows with dystocia, retained fetal membranes and reduced the interval from parturition to conception, or both (Nakao et al., 1997). In another study (Seals et al., 2002), peripheral PGFM concentra- tions were lower in postpartum dairy cows that subsequently developed uterine infection than those that did not develop uterine infections. More recently, Melendez et al. (2004) reported that exogenous $\mathrm{PGF}_{2 \alpha}$ decreased the diameter of uterine horns at $d 12$ postpartum and increased the first-service conception rate in primiparous Holstein cows with acute puerperal metritis. Finally, the observation that $\mathrm{PGF}_{2 \alpha}$ was chemoattractant to neutrophils (Hoedemaker et al., 1992) and increased their bactericidal activity in vitro (Watson, 1988) would indicate that changes in uterine production of $\mathrm{PGF}_{2 \alpha}$ may enhance the neutrophil function in early postpartum cows, thereby improving their defense mechanism against bacterial infection after calving.

Human studies have shown that $t \mathrm{FA}$ intake increases systemic inflammation through the production of inflammatory cytokines (Han et al., 2002). In the present study, dietary $t$ FA had no detectable effects on plasma TNF- $\alpha$ and IL- 4 concentrations in postpartum Holstein cows. The discrepancy between our findings and those reported previously (Han et al., 2002) may reflect species or $t \mathrm{FA}$ isomeric differences between the two studies. Additionally, discrepancies between human and animal studies may be related to differences between doses and durations of fat supplementation. At best, our data would indicate that, in cattle, dietary $t$ FA may affect uterine health and postpartum reproductive efficiency through alteration of uterine $\mathrm{PGF}_{2 \alpha}$ production, and that this effect does not involve alteration of plasma concentration of inflammatory cytokines.

\section{CONCLUSIONS}

Results of this study provide no evidence for $t \mathrm{FA}$ modulation of production, metabolic, and cytokine responses in early lactation Holstein cows. The greater plasma PGFM concentration detected in multiparous cows fed a $t$ FA-supplemented diet raises the possibility that peripartum $t \mathrm{FA}$ supplementation may improve 
uterine health and postpartum reproductive efficiency of dairy cows through alteration of peripheral $\mathrm{PGF}_{2 \alpha}$ concentration.

\section{ACKNOWLEDGMENTS}

The authors are grateful to William W. Thatcher (Department of Animal Sciences, University of Florida) for the generous gift of bovine PGFM antibody. Appreciation is extended to Cargill (Minneapolis, MN) and Virtus Nutrition (Fairlawn, OH) for kindly providing SF and $t \mathrm{FA}$ supplements for this study.

\section{REFERENCES}

AOAC. 1990. Official Methods of Analysis. 15th ed. Assoc. Off. Anal. Chem., Arlington, VA.

Beare-Rogers, J. L. 1988. Trans and positional isomers of common fatty acids. Adv. Nutr. Res. 5:171-200.

Bernal-Santos, G., J. W. Perfield II, D. M. Barbano, D. E. Bauman, and T. R. Overton. 2003. Production responses of dairy cows to dietary supplementation with conjugated linoleic acid (CLA) during the transition period and early lactation. J. Dairy Sci. 86:3218-3228.

Bonnett, B. N., W. G. Etherington, S. W. Martin, and W. H. Johnson. 1990. The effect of prostaglandin administration to HolsteinFriesian cows at day 26 postpartum on clinical findings, and histological and bacteriological results of endometrial biopsies at day 40. Theriogenology 33:877-890.

Castaneda-Gutierrez, E., T. R. Overton, W. R. Butler, and D. E. Bauman. 2005. Dietary supplements of two doses of calcium salts of conjugated linoleic acid during the transition period and early lactation. J. Dairy Sci. 88:1078-1089.

Curtis, C. R., H. N. Erb, C. J. Sniffen, R. D. Smith, and D. S. Kronfeld. 1985. Path analysis of dry period nutrition, postpartum metabolic and reproductive disorders, and mastitis in Holstein cows. J. Dairy Sci. 68:2347-2360.

Gilbert, R. O., Y. T. Grohn, P. M. Miller, and D. J. Hoffman. 1993. Effect of parity on periparturient neutrophil function in dairy cows. Vet. Immunol. Immunopathol. 36:75-82.

Goff, J. P., and R. L. Horst. 1997. Physiological changes at parturition and their relationship to metabolic disorders. J. Dairy Sci. 80:1260-1268.

Grohn, Y. T., H. N. Erb, C. E. McCulloch, and H. S. Saloniemi. 1990. Epidemiology of reproductive disorders in dairy cattle: Associations among host characteristics, disease and production. Prev. Vet. Med. 8:25-39.

Gurr, M. I. 1983. Trans fatty acids. Int. Dairy Fed. Bull. 166:6-18.

Han, S. N., L. S. Leka, A. H. Lichtenstein, L. M. Ausman, E. J. Schaefer, and S. N. Meydani. 2002. Effect of hydrogenated and saturated, relative to polyunsaturated, fat on immune and inflammatory responses of adults with moderate hypercholesterolemia. J. Lipid Res. 43:445-452.

Hoedemaker, M., L. A. Lund, and W. C. Wagner. 1992. Influence of arachidonic acid metabolites and steroids on function of bovine polymorphonuclear neutrophils. Am. J. Vet. Res. 53:1534-1539.

Kepler, C. R., K. P. Hirons, J. J. McNeill, and S. B. Tove. 1966. Intermediates and products of the biohydrogenation of linoleic acid by Butyrivibrio fibrisolvens. J. Biol. Chem. 241:1350-1354.

Lessard, M., N. Gagnon, and H. V. Petit. 2003. Immune response of postpartum dairy cows fed flaxseed. J. Dairy Sci. 86:2647-2657.

Lewis, G. S., and M. C. Wulster-Radcliffe. 2006. Prostaglandin $\mathrm{F}_{2 \alpha}$ upregulates uterine immune defenses in the presence of the immunosuppressive steroid progesterone. Am. J. Reprod. Immunol. 56:102-111.

Mahfouz, M. M., and F. A. Kummerow. 1999. Hydrogenated fat high in trans monoenes with adequate level of linoleic acid has no effect on prostaglandin synthesis in rats. J. Nutr. 129:15-24.
Mattos, R., C. R. Staples, A. Arteche, M. C. Willbank, F. J. Diaz, T. C. Jenkins, and W. W. Thatcher. 2004. The effects of feeding fish oil on uterine secretion of $\mathrm{PGF}_{2 \alpha}$, milk composition, and metabolic status of periparturient Holstein cows. J. Dairy Sci. 87:921-932.

McCracken, J. A., J. C. Carlson, M. E. Glew, J. R. Goding, D. T. Baird, K. Green, and B. Samuelsson. 1972. Prostaglandin $\mathrm{F}_{2 \alpha}$ identified as a luteolytic hormone in sheep. Nat. New Biol. 238:129-134.

Melendez, P., J. McHale, J. Bartolome, L. F. Archbald, and G. A. Donovan. 2004. Uterine involution and fertility of Holstein cows subsequent to early postpartum $\mathrm{PGF}_{2 \alpha}$ treatment for acute puerperal metritis. J. Dairy Sci. 87:3238-3246.

Meydani, S. N., and C. A. Dinarello. 1993. Influence of dietary fatty acids on cytokine production and its clinical implications. Nutr. Clin. Pract. 8:65-72.

Mozaffarian, D., T. Pischon, S. E. Hankinson, N. Rifai, K. Joshipura, W. C. Willet, and E. B. Rimm. 2004a. Dietary intake of trans fatty acids and systemic inflammation in women. Am. J. Clin. Nutr. 79:606-612.

Mozaffarian, D., E. B. Rimm, I. B. King, R. L. Lawler, G. B. McDonald, and W. C. Levy. 2004b. Trans fatty acids and systemic inflammation in heart failure. Am. J. Clin. Nutr. 80:1521-1525.

Nakao, T., A. Gamal, T. Osawa, K. Nakada, M. Moriyoshi, and K. Kawata. 1997. Postpartum plasma PGF metabolite profile in cows with dystocia and/or retained placenta, and effect of fenprostalene on uterine involution and reproductive performance. J. Vet. Med. Sci. 59:791-794.

Piperova, L. S., U. Moallem, B. B. Teter, J. Sampugna, M. P. Yurawecz, K. M. Morehouse, D. Luchini, and R. A. Erdman. 2004. Changes in milk fat in response to dietary supplementation with calcium salts of trans-18:1 or conjugated linoleic fatty acids in lactating dairy cows. J. Dairy Sci. 87:3836-3844.

Seals, R. C., I. Matamoros, and G. S. Lewis. 2002. Relationship between postpartum changes in 13,14 -dihydro-15-keto-PGF ${ }_{2 \alpha}$ concentrations in Holstein cows and their susceptibility to endometritis. J. Anim. Sci. 80:1068-1073.

Shah, P., A. Vella, A. Basu, R. Basu, A. Adkins, W. F. Schwenk, C. M. Johnson, K. S. Nair, M. D. Jensen, and R. A. Rizza. 2002. Effects of free fatty acids and glycerol on splanchnic glucose metabolism and insulin extraction in nondiabetic humans. Diabetes 51:301-310.

Strang, B. D., S. J. Bertics, R. R. Grummer, and L. E. Armentano. 1998. Effect of long-chain fatty acids on triglyceride accumulation, gluconeogensis, and ureagenesis in bovine hepatocytes. J. Dairy Sci. 81:728-739.

Thatcher, W. W., F. F. Bartol, J. J. Knickerbocker, J. S. Curl, and D. Wolfenson. 1984. Maternal recognition of pregnancy in cattle. J. Dairy Sci. 67:2797-2811.

Van Soest, P. J., J. B. Robertson, and B. A. Lewis. 1991. Methods for dietary fiber, neutral detergent fiber, and nonstarch polysaccharides in relation to animal nutrition. J. Dairy Sci. 74:35833597.

Wander, R. C., J. A. Hall, J. L. Gradin, S.-H. Du, and D. E. Jewell. 1997. The ratio of dietary (n-6) to (n-3) fatty acids influences immune system function, eicosanoid metabolism, lipid peroxidation and vitamin E status in aged dogs. J. Nutr. 127:1198-1205.

Watson, E. D. 1988. Eicosanoids and phagocytic and bactericidal activity of equine neutrophils. Equine Vet. J. 20:373-375.

Weggemans, R. M., M. Rudrum, and E. A. Trautwein. 2004. Intake of ruminant versus industrial trans fatty acids and risk of coronary heart disease-What is the evidence? Eur. J. Lipid Sci. Technol. 106:390-397.

Wiggans, G. R. 1986. Estimating daily yields of cows milked three times a day. J. Dairy Sci. 69:2935-2940.

Wolff, R. L., D. Precht, and J. Molkentin. 1998. Occurrence and distribution profiles of trans-18:1 acids in edible fats of natural origin. Pages 1-33 in Trans fatty acids in human nutrition. J. L. Sebedio and W. W. Christie, ed. The Oily Press, Dundee, UK.

Yaqoob, P., and P. C. Calder. 1995. The effect of dietary lipid manipulation on the production of murine T-cell-derived cytokines. Cytokine 7:548-553. 